\title{
How does Victim Precipitation Theory explain Deviant Behaviours of Internet Romance Offenders? Gamer's Perspective of Victim Precipitation
}

\author{
Martin Otu Offei \\ Department of Computer Science, Koforidua Technical University, Koforidua, Ghana \\ Email: martin.offei@ktu.edu.gh
}

\begin{abstract}
Internet romance fraud is a global canker with severe consequences to the victims ranging from significant financial loss, emotional trauma, to loss of life and property. The paper examines how internet romance offenders rationalize their deviant criminal behaviours and how these criminals use victim precipitation to commit internet romance fraud. The three dimensions of victim precipitation theory in this study are victim facilitation, victim provocation and victim openness. The research explains how internet romance offenders rationalize and justify their deviant behaviour. The data from this research model elicited 320 individual responses from hotspots associated with internet fraud activities. The findings from this study highlight the conditions under which victim precipitation theory dimensions in the context of internet romance fraud occur. The findings shows that offenders of internet romance fraud rely heavily on victim precipitation to perpetuate their criminal activities: all the three dimensions studied are used by these criminals as justification techniques to increases offenders' predisposition to commit internet romance fraud. All three victim precipittion techniues ae used; victim openness, victim facilitation and victim provocation, respectively. This expands the boundaries of victim precipitation theory. The study contributes to new dimensions of victim precipitation in online romance fraud. This study has theoretical and criminology implications; and it gives a new perspective of how victims should conduct themselves in internet romance fraud cases. It also enriches the debate of victim precipitation in criminology discipline.
\end{abstract}

Keywords: Online romance fraud, offenders, victim precipitation theory, scam, internet fraud

Citation: Offei, M. O. (2021). How does Victim Precipitation Theory explain Deviant Behaviours of Internet Romance Offenders? Gamer's Perspective of Victim Precipitation. International Journal of Technology and Management Research (IJTMR), Vol. 6 (2): Pp.59-72

Received: March 3, 2021

Accepted: September 1, 2021 


\subsection{Introduction}

Many persons use online dating platforms to scam victims financially and emotionally, a practice known as internet romance fraud. Those who use this means to defraud people are internet romance fraudsters who identify victims as "clients" and not "victims". They see them as clients because those targeted are in need of a particular service that the offenders perceive they can provide. In the view of the offenders, their clients are looking for something they are prepared to pay for. Their clients are looking for a romantic relationship that is mutual between two consenting adults, without suspecting the intent of the offender, which is criminal. They use love as a bait to lure their victims and eventually defraud them of their money.

Recruitment of fraud victims is normally done on dating sites, chat rooms and social networking platforms. These online platforms provide the virtual meeting place for the victims and the perpetrators. These online platforms present an opportunity to initiate the love journey with offenders who are mostly from developing countries, while their victims are mostly from the western world. The offenders have a clear intention to deceive and defraud their victims. While the victims are looking for love from these social media platforms, offenders, on the other hand, are looking for victims to swindle. Offenders use all sort of tricks including forgery, false presence and impersonation to outwit their victims who have no idea of the real intention of these criminals (Ibrahim, 2016; Barnor et al., 2020). Both the victim and the offender have their intentions clearly set out in their thoughts and subsequent future actions. In effect, both the offenders and their victims are victims in their own rights. The offender may be looking for financial gain while the online victim may be longing for love. While the victim assumes they have found romantic love and are burnt on consuming it, the offender sees an opportunity to make money from the victim. The love that is shared by the victim and the offender makes this type of cybercrime unique thereby requiring the needed attention from practitioners and academia (Cross, 2018). Internet fraud is been given the needed attention in disciplines such as information systems and criminology among others (Williams et al., 2017).

The novelty of these crimes is as a result of the advancement of information, communication, technologies (ICT) and the emergence of social media platforms that are being re-engineered with the connection of so many persons who hold a common interest in the world (Rege, 2009). These offenders sometimes work collaboratively with their counterparts around the world by moving bulky cash transaction through different countries (U.S. Department of Justice, 2019). By so doing, they elude law enforcement agencies because of the different laws that exist within these routing countries. The non-conformity of the justices system across the routing countries makes it difficult for law enforcement to adequately deal with these criminals (Hadzhidimova \& Payne, 2019).

From the perspective of the online romance offenders, the victims are clients who have the intention to trade love for the any material things they possess. For them, love is on sale. They first met on a dating site where they see their personal profiles, shared this profile and a friends request, when this friendship request is accepted by the other party then a mutual romantic friendship ensue among them. This friendship blossoms to a point where trust is developed to the point of exchanging gifts. While the offender's intention is to extract money and material things, the intention of the client is to find love and friendship. Killing loneliness and being loved romantically but all this comes with cost from the offender, love is not free. 
There are many controversies surrounding victim precipitation because one of the fundamental characteristics associated with this theory is that victims sometimes imitate and contribute to their losses (Petherick, 2017; Dhanani et al., 2019). While other theories of criminology focus on the offender, victim precipitation looks at the relationship that the offenders and their victims share; the relationship that necessitates the crime committed against the victims. Hans von Hentig (1887-1974), the father of victim precipitation, posits that crime will have to be looked at from all dimensions including the victim's contribution to the crime against them. They argue that victims sometimes contribute to their loss by association with the offenders. Victim precipitation is among the pioneer theories of victimology, and argues that victims contribute to their losses unintentionally. Victims cannot recuse themselves from the crimes that offenders perpetuate on them as they are partially responsible for such crimes. According to Von Hentig (1940), the behavior of victims, their characteristics and their predisposition exposes them to crimes visited on them by offenders.

According to Lasky (2019), victims contribute to crimes against them either through facilitation or provocation. Victim facilitation is helping offenders unintentionally create the required environment for the crime to occur. Victim provocation, on the other hand, is when victims putting themselves in the path that invite the crime against them to be perpetuated. Victim openness involves the trust and the lifestyle of victims, and sharing too much personal information with the offenders, which opens the victims up to be defrauded (Meier \& Miethe, 1994; Warner, 2011; Angkasa, 2018; Lazarus, 2018).

The Facebook page of Indonesia's police cybercrime records that most cybercrime perpetuated against victims is through victim precipitation. These many interaction among the victims and their offenders make the victim precipitation theory applicable. The continuous interaction of these groups of persons build trust, which makes victims susceptible to the deceit that characterizes internet romance fraud. Trust in build over time, this trust increases the vulnerability of the victims. The interaction heightens the expectation of the offender who is expecting something in return from their relationship; often times financial reward for their time and energy spent on the victim.

From the criminology point of view, these offenders see their victims as clients, thereby rationalizing their criminal behaviours by victim precipitation. They see their victims as their partners, thereby reinforcing the assertion that victims of crime sometimes participate and contribute to the harm or loss that they sustain, either though victim facilitation or victim provocation. According to Lasky (2020), victim facilitation contributes to their being a party to the event that led to them to being victimize. Irrespective of the intention, victim provocation results from victims clearly behaving in the way that exposes them to be victimized. The awareness of internet romance fraud is highlighted in the western world with disclaimers given on dating sites; yet these victims, because they are looking for love, expose themselves to these offenders to take advantage of them. They offenders offer love services online that these clients do not get from their recipient countries. In exchange, the victims pay dearly for their acceptance of love from these criminals from their dating websites without knowing the intent of these online romance offenders. 


\subsection{Key Literature}

Table 1: Key Literature on Internet Romance Fraud

\begin{tabular}{|c|c|c|c|c|c|}
\hline $\mathrm{S} / \mathrm{N}$ & Author / Authors & Paper title & Constructs & Context & Method \\
\hline 1 & Warner (2011) & $\begin{array}{l}\text { Understanding Cyber-Crime in } \\
\text { Ghana: A View } \\
\text { from Below }\end{array}$ & $\begin{array}{l}\text { The techno-spiritual } \\
\text { paradigm and } \\
\text { justificatory } \\
\text { philosophies of } \\
\text { social justice }\end{array}$ & Victim & Qualitative \\
\hline 2 & $\begin{array}{l}\text { Dhanani et al. } \\
\text { (2019) }\end{array}$ & $\begin{array}{l}\text { Do you only have yourself to } \\
\text { blame? A meta-analytic test of } \\
\text { the victim precipitation model }\end{array}$ & $\begin{array}{l}\text { "Victim disposition } \\
\text { Trait negative } \\
\text { affectivity } \\
\text { Victim neuroticism } \\
\text { Victim } \\
\text { agreeableness } \\
\text { Victim } \\
\text { conscientiousness } \\
\text { Victim extraversion } \\
\text { Victim openness" }\end{array}$ & Victim & Quantitative \\
\hline 3 & Lasky (2019) & $\begin{array}{l}\text { Victim Precipitation } \\
\text { Theory }\end{array}$ & Victim Precipitation & Victim & $\mathrm{N} / \mathrm{A}$ \\
\hline 4 & $\begin{array}{l}\text { Barnor et al. } \\
(2020)\end{array}$ & $\begin{array}{l}\text { Rationalizing Online Romance } \\
\text { Fraud: In the Eyes of the } \\
\text { Offender }\end{array}$ & None & & Qualitative \\
\hline 5 & Whitty (2017) & $\begin{array}{l}\text { Do You Love Me? } \\
\text { Psychological } \\
\text { of Romance Scam Victims }\end{array}$ & None & Victim & Qualitative \\
\hline 6 & Angkasa (2018) & $\begin{array}{l}\text { Legal Protection for Cyber } \\
\text { Crime Victims on } \\
\text { Victimological Perspective }\end{array}$ & Victim Precipitation & Victims & Qualitative \\
\hline 7 & Petherick (2017) & $\begin{array}{l}\text { Victim Precipitation: Why We } \\
\text { Need to Expand Upon the } \\
\text { Theory }\end{array}$ & Victim Precipitation & Victims & Qualitative \\
\hline
\end{tabular}




\begin{tabular}{lllll}
\hline 8 Petherick and & Victim Precipitation: An Victim Precipitation Victims & Qualitative \\
Brooks (2020) & Outdated Construct or an & & \\
& Important Forensic \\
& Consideration? \\
$9 \quad$ Offei et al. (2020) & How Do Individuals Justify Denial of risk and Offenders Quantitative \\
& and Rationalize their Criminal neutralization \\
& Behaviors in Online Romance \\
& Fraud?
\end{tabular}

This paper argues that these victims contribute significantly either through provocative or facilitative or openness to their losses of cash and other valuables from the perspective of the offenders.

The inconsistency of victim precipitation theory in diverse criminal behavioural reign enforces the need to empirically study the theory in another context. Victim precipitation does no exonerate the offender of the crime in any way, but does give credence to that fact that the victim might be a partner and a facilitator of the crime committed against them. There is the need to fully understand the intent and motivation from the perspective of the offender. The romantic relationship over the internet on dating sites provides a framework to critically examine victim precipitation techniques as justification for committing online romance fraud. The research hypothesises that;

H1: Internet romance fraudsters perceive that victims facilitate positively influce their relationship with the intention to commit internet romance frand

Online romance fraud gives victims and offenders the opportunity to have a romantic relationship online, and during this relationship the offender invests time and resources to sustaining the relationship. However, these offenders spend most of their time and resources to cultivate their relationship with their victims, offenders buy gifts, including flowers, chocolates, rings, food and sometime toiletries just to make their victims appreciate their kindness The relationship, which is predominantly between a developing country offender and a western country victim, has the tendency to provocative the offender who has the intent of benefiting from this relation to the detriment of the victim they call a client.

These offenders are incentivized by the continuous interaction with their victims, and by their actions these victims promote their own victimization. As a result we hypothesise that;

H2: Internet romance fraudsters perceive that victims provocation positively influence their intention to commit internet romance frand.

Openness, according to Costa and McCrae (1995), presents the ability to accept different views, have a critical mind and challenge conservative ideas. According to Sliter et al. (2015), openness as a victim precipitation variable has received little attention and there is a need to continuums investigate how openness attracts 
offenders to victims. Sliter et al. (2015) further argue that persons who are more open may be attracted unintentionally to offenders because they do not perceive their offenders initially as criminals. However, Mathisen.Øggard, and Einarsen (2012) contrast this assertion in their study on workplace mistreatment at the organizational level, which shows that openness does not necessarily attract mistreatment. However, we argue that openness of victims during internet romance contributes to them being victims of fraud. We hypothesise that;

H3: Victim openness positively influences the relationship between the victim and the intention to commit internet romance fraud.

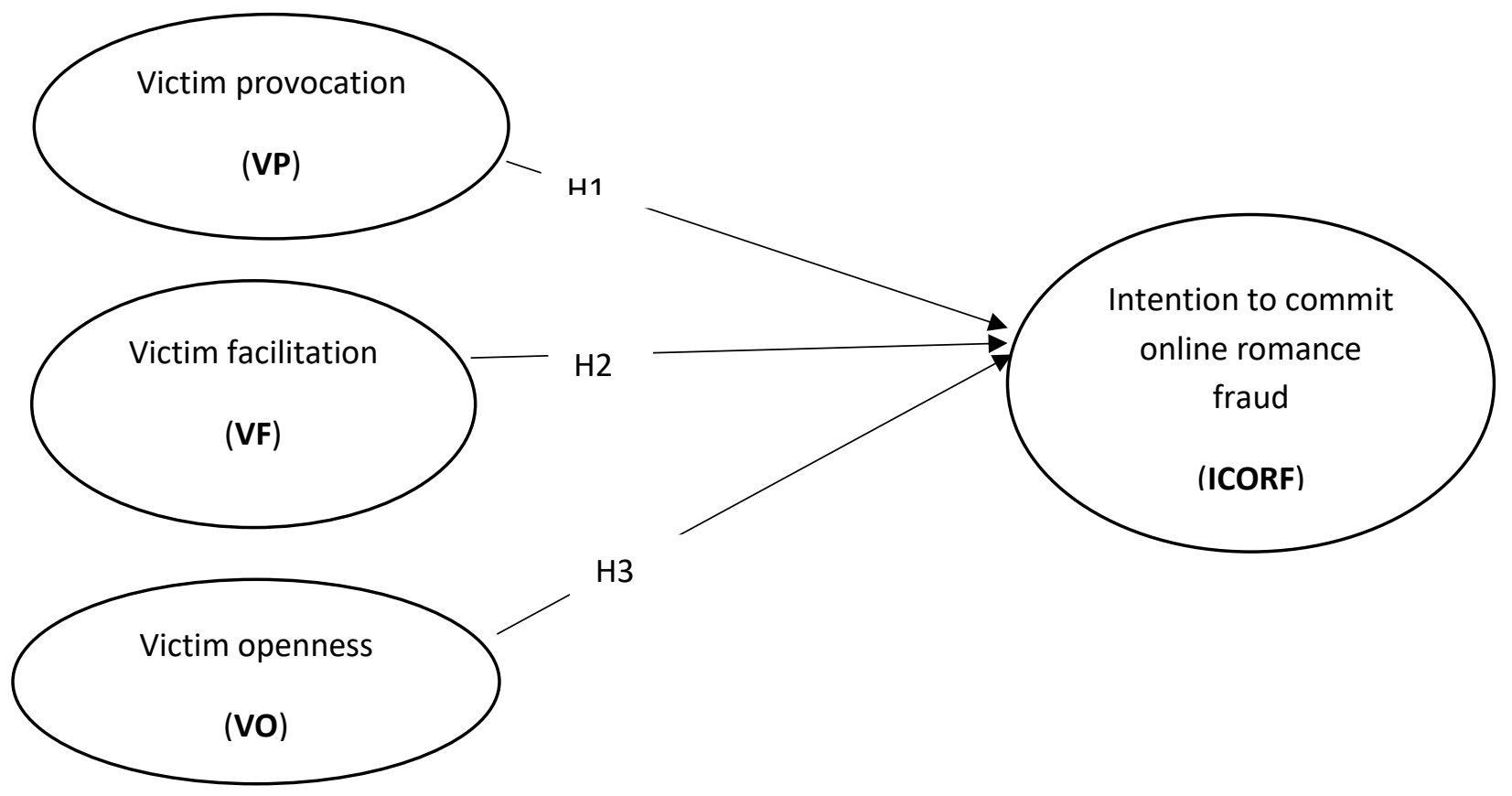




\subsection{Methodology}

\subsection{Context of the Study}

The research targeted a population of internet romance fraudsters who understand what they do and have known their victims over a period of time. These offenders are called "gamers" and they are often young persons who are about 16 years of age. The offenders refer to their victims as "clients". Gamers see their clients as people with whom they transact business without the victims knowing that they are transactional partners of these gamers. Due to the anonymous nature of the internet and how private online love relationships are, snowball and convenience sampling techniques were combined as internet hotspots were the main target areas. The internet cafes are public places where individuals have private booths where they practice their trade, and constitute the recruiting grounds for both new gamer entrants and as a workshop to practice fraud activities. Table 1 represents the descriptive statistics for the gamers.

\subsection{Measurement and Instrumentation}

A 5-point Likert-type scale was used as a measurement tool to elicit responses from the gamers. The subconstructs of victims' precipitation adapted for this study is victim provocation, victim facilitation (Lasky, 2020) and victim openness (Sliter et al., 2015; Dhanani et al., 2019). These dimensions for victims' precipitation are adapted and applied to the context of internet romance fraud. Offenders suggest that victims' activities contribute significantly to them being defrauded. Victim facilitation, provocation and openness are modelled as first order reflective variables of victim precipitation with observables measuring different aspects of victim precipitation in the context of internet romance fraud. Content validity was ensured through meeting twice for a period of three hours each with 10 practitioners of internet romance fraudsters and two information systems experts to validate these contracts. Furthermore, to ensure construct validity a 60 -sample study was conducted as the second face of validity and the measurement instrument revised to improve the quality of constructs. The instruments that represent the final survey are represented in Table 2.

\subsection{Collection of Data}

The study sample data includes responses from different internet fraud café hotspots, which are the main areas within which internet romance fraud takes place. Data was elicited by referrals of internet romance fraudsters who are aware of their associates involvement in internet romance fraud activities.

The secrecy and anonymity of internet romance fraud make it difficult to know the population of internet romance fraudsters. The sample technique used was convenient, with 350 questionnaires administered to internet romance fraudsters hotspots as well as the the referrals of internet romance fraudsters. A total of 320 responses were received from the respondents, which represents an $80 \%$ response rate. The majority of respondents $(99.1 \%)$ are between the ages of 18-40 years and the average educational bacground of these respondents is at least senior high school. Table 2 below represents the demographic representation of the respondents in this study. 
Table 2: Demographic Representation

\begin{tabular}{|c|c|c|c|c|}
\hline Control Variables & Frequency & Percentage & $\begin{array}{l}\text { Valid } \\
\text { Percent }\end{array}$ & $\begin{array}{l}\text { Cumulative } \\
\text { Percentage }\end{array}$ \\
\hline \multicolumn{5}{|l|}{ Age } \\
\hline$<20$ years & 127 & 39.7 & 39.7 & 39.7 \\
\hline $21-30$ years & 147 & 45.9 & 45.9 & 85.6 \\
\hline $31-40$ years & 43 & 13.4 & 13.4 & 99.1 \\
\hline $41-50$ years & 3 & 0.9 & 0.9 & 100 \\
\hline \multicolumn{5}{|l|}{ Gender } \\
\hline Male & 237 & 74.1 & 74.1 & 74.1 \\
\hline Female & 83 & 25.9 & 25.9 & 100 \\
\hline \multicolumn{5}{|l|}{ Educational Level } \\
\hline Basic & 57 & 17.8 & 17.8 & 17.8 \\
\hline Secondary & 189 & 59.1 & 59.1 & 76.9 \\
\hline Tertiary & 74 & 23.1 & 23.1 & 100 \\
\hline \multicolumn{5}{|c|}{ Access to internet device } \\
\hline Yes & 311 & 97.2 & 97.2 & 97.2 \\
\hline No & 9 & 2.8 & 2.8 & 100 \\
\hline \multicolumn{5}{|c|}{ Level of computer competence or skills } \\
\hline Extremely Competent & 71 & 22.2 & 22.2 & 22.2 \\
\hline
\end{tabular}




\begin{tabular}{l|l|l|l|l} 
Very Competent & 124 & 38.8 & 38.8 & 60.9 \\
\hline Competent & 111 & 34.7 & 34.7 & 95.6 \\
\hline Rarely Competent & 14 & 4.4 & 4.4 & 100 \\
\hline ORF Experience & & & & \\
\hline Yes & 316 & 98.8 & 98.8 & 98.8 \\
\hline No & & & & \\
\hline Rate of Level of Experience (skills) & 4 & 1.3 & 1.3 & 100 \\
\hline Extremely Experience & & & & \\
\hline Very Experience & 124 & 38.8 & 38.8 & 38.8 \\
\hline Experience & 110 & 34.4 & 34.4 & 73.1 \\
\hline Rarely Experience & 81 & & & \\
\hline Not Experience & 3 & 0.9 & 25.3 & 98.4 \\
\hline
\end{tabular}

\subsection{Results and Discussions}

\subsection{Analysis and Results}

Victimology theory has been used to explain how victims of crimes have directly or indirectly contributed to being harmed by their offenders. Victim precipitation suggests that victims of fraud's interaction with offenders ultimately contribute to them being swindled or harmed as, according to Angkasa (2018), "how victim's interaction with an offender may contribute to the crime being committed". The theoretical model of the study is based on three victim precipitation dimensions, namely victim provocation, victim facilitation and victim openness. This model is an explanatory in nature with three dimensions of victim precipitation in the context of internet romance fraud. A covariance-based structural model was used to confirm these dimensions of victim precipitation theoretically, and to see how this can help predict future accuracy of this model. A structural model assessment was done by using SmartPLS.

\subsection{Measurement Model Validation}

To ascertain model measurements of validity, reliability and common method-biased co-variance, SEM was employed with SmartPLS software to ensure psychometric properties were properly analyzed. Construct validity was examined by using the measurements of convergent and discriminant validity: these two measurements represent Confirmatory factor analysis (CFA). The following results of the model measurement represents a rigorous 
psychometric property. Construct reliability (CR), Cronbach alpha (CA), Average variance extracted (AVE), rho A, HTMT, and Fornel lacker resents consturct relaibity and coverget validity.

The reliability of variables under study can also be assessed by using convergent validity, variable reliability, average variance extracted (AVE) and performing factor analysis (Fornell \& Larcker, 1981). To ensure that this measure is reliable, the loading of variables or construct whose loading are insignificant are removed to make certain that the construct under study is adequately represented by the measures, and the cross loading of constructs were noted to be insignificant. Table 3 is the composite reliability construct under study. Victim provocation ( $P V P=0.886$, victim facilitation (PVF=0.886), victim openness $(\mathrm{PVO}=0.978)$ and intention to commit internet romance fraud (ICIRF $=0.984$ ), the AVE for the constructs ranges from (0.745-.0.896) meeting the threshold value of 0.7 (Hair Jr et al., 1995).

Table 3: Constructs Reliability

\begin{tabular}{llllll}
\hline Constructs & CR & AVE & $\mathbf{R}^{2}$ & CA & rho_A \\
Victim Provocation (PVP) & 0.886 & 0.849 & 0.625 & 0.807 & $\mathbf{0 . 8 9 3}$ \\
Victim Facilitation (PVF) & 0.924 & 0.896 & 0.715 & 0.877 & $\mathbf{0 . 8 1 4}$ \\
& 0.978 & 0.75 & 0.825 & 0.706 & $\mathbf{0 . 8 7 8}$ \\
Victim Openness (VPO) & & & & & $\mathbf{0 . 7 6 7}$ \\
$\begin{array}{l}\text { Intention to commit internet romance fraud-deception } \\
\text { (ItcirfD) }\end{array}$ & 0.868 & 0.745 & 0.712 & 0.807 & \\
$\begin{array}{l}\text { Intention to commit internet romance fraud-intention } \\
\text { (ItcirfId) }\end{array}$ & 0.866 & & & & \\
\hline
\end{tabular}

Discriminant validity of each latent constructs was tested by the method recommended by Fornell and Larcker (1981) and AVE of each construct (diagonal of Table 4.

Table 4: Discriminant Validity

\begin{tabular}{lllll}
\hline Constructs & VPP & VPF & VPO & ICIRF \\
VPP & $\mathbf{0 . 8 4 9}$ & & & \\
VPF & 0.483 & $\mathbf{0 . 8 9 6}$ & & \\
VPO & 0.22 & 0.398 & $\mathbf{0 . 7 5}$ & \\
ICIRF & 0.382 & 0.496 & 0.19 & $\mathbf{0 . 7 3 1}$ \\
\hline
\end{tabular}

\subsection{Structural Model and Hypotheses Testing}

According to Hair et al. (2019), when reliability parameters are established then there is a need to test for the model fitness. The path coefficients and the t-values for the research model are represented in Table 5. The strength of model is revealed by the relationship between the victim precipitation constructs and the intention to commit internet romance fraud constructs. The model reveals that the three dimensions of victim precipitation (victim provocation, 
victim facilitation and victim openness) positively influence intention to commit internet romance fraud. Victim openness ((0.693), 28.855) is the strongest among these three with victim participation $(\mathbf{( 0 . 3 6 1 ) / 5 . 6 4 7 )}$ and victim facilitation $((0.315) / 3.144)$ following.

The structural model results revealed that all pathways in the study model are statistically significant. The path of VPO is the most significant positive relationship with intention to commit internet romance fraud in the study context $(\mathrm{b}=0.693, \mathrm{t}=28.855, \mathrm{p}>0.05)$. Thus, $\mathrm{H} 3$ is supported. $\mathrm{H} 1$ is also supported $(\mathrm{b}=0.361, \mathrm{t}=5.647, \mathrm{p}>0.05)$ as victim participation is significantly related to the intention to commit internet romance fraud (ICRF) in the context of this study. H2, which posits that victim facilitation positively influences intention to commit internet romance fraud,was supported $(b=0.315, t=3.144, p<0.05)$. Table 6 below shows $\mathrm{R}^{2}, \mathrm{t}$-values, and $\mathrm{p}$ values; and figure 2 shows path coefficients.

\begin{tabular}{llllll}
\hline Hypotheses & $\begin{array}{l}\text { Victim Precipitation } \\
\text { Dimensions }\end{array}$ & $\mathbf{R}^{2}$ & T-values & P-values & Support? \\
& VPP-> ICIRF & 0.561 & 5.647 & 0.000 & Supported \\
H1 & VPF-> ICIRF & 0.566 & 3.144 & 0.000 & Supported \\
H2 & VPO -> ICIRF & 0.693 & 28.855 & 0.000 & Supported \\
H3 & & & & & \\
\hline
\end{tabular}

Table 5: Research Model Results
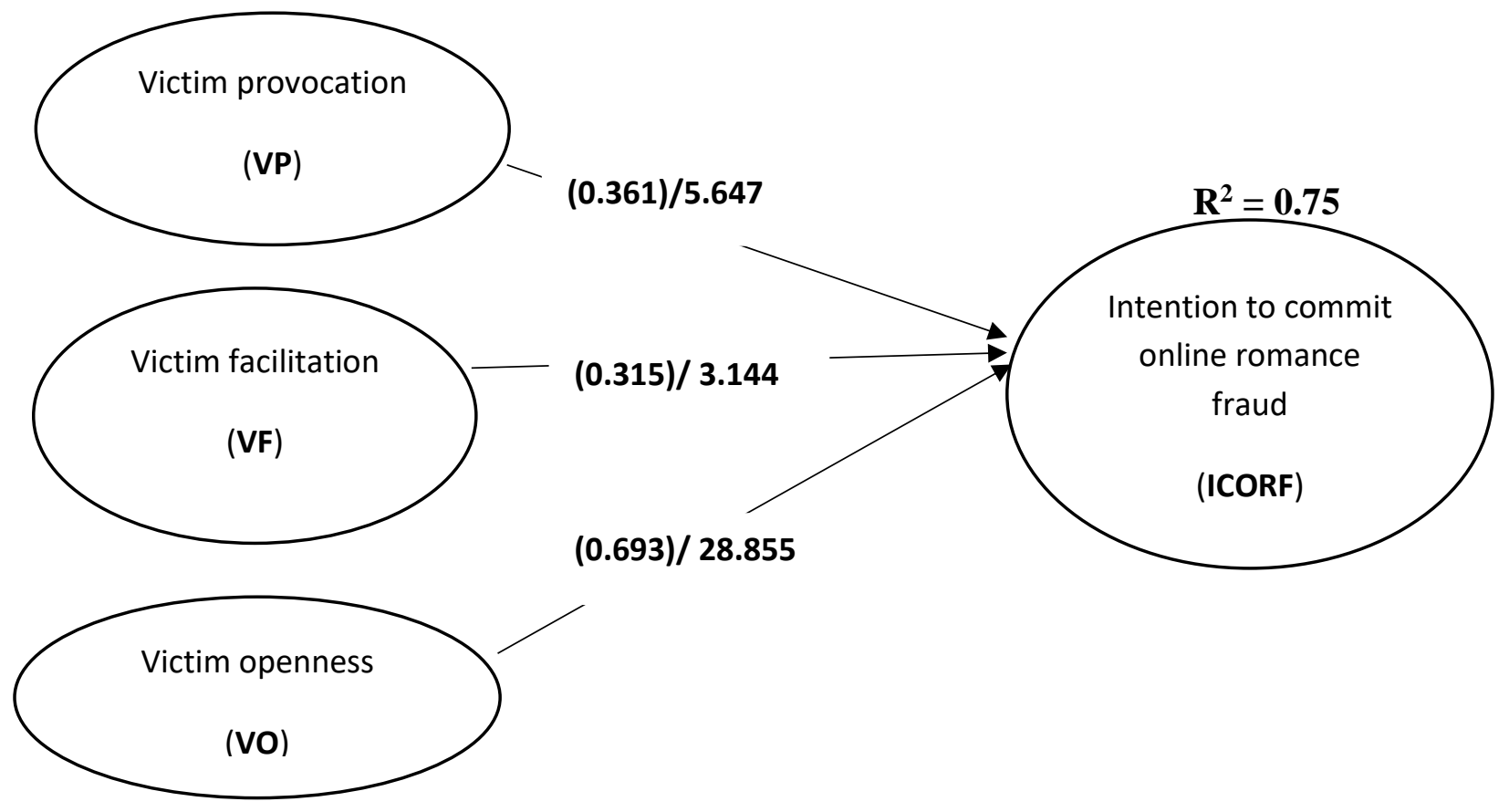

Figure 2: Research model 
In criminology literature, victimology is the study of victims and, according to Lasky (2019), victimization is the study of victim's involvement in a crime situation. Victim precipitation emerged from victimology and had different constituents classified by persons who developed victimology in the early stages of the theory (Lasky, 2019). Victim precipitation asserts that victims contribute or initiate the harm that offenders mete out to them. The harm or loss that happens is sometimes initiated by the victims themselves (Petherick, 2017). According to Petherick (2017), victim precipitation is a contentious theory that should not be ignored although it is not popular among practitioners and society. In criminology literature victim precipitation in different context is inconsistent (Meier \& Miethe, 1994; Petherick et al., 2021).

Lasky (2019) identified two dimension of victim precipitation, namely victim participation and victim facilitation. However, in Dhanani et al. (2018) in an article titled, "Do you only have yourself to blame? A meta-analytic test of the victim precipitation model", this model identified (among other dimension of victim precipitation) victim openness, which this study used and operationalized because it is fit for purpose in the context of internet romance fraud. The three dimensions of victim precipitation that were operationalize for the purpose of this study are; victim participation, victim facilitation and victim openness due to what Petherick (2017). Most of the criminology literature does not operationalize these constructs to obtain empirically evidence to enrich the literature. This study seeks to bridge the gap suggested by other studies. "These include inadequate attention to variation by type of crime, compartmentalized thinking, poor links between theory and data, inadequate measures of key concepts, and failure to specify clearly functional relationships between sets of variables" (Meier \& Miethe, 1994). The context of the literature does not include internet romance fraud. The context of victim precipitation is adaptive and can be applied in internet romance, which has been given no attention in the information systems and criminology literature. According to Canter and Youngs (2009), "The victim-offender role provides a fundamental structure that is diverse and flexible, capable of accommodating different contexts and presentations".

According to Petherick et al. (2020), the focus of victim precipitation should be behavioural: the victim behaves in a way that contribute to their being defrauded in that they are overly open $(\mathbf{0 . 6 9 3}), 28.855)$ to their online fraud partners who get to know so much about them and subsequently take advantage of them. This concept is supported by Mathisen et al. (2012) and contradicted by Dhanani et al. (2018) in different contexts. The social reality can facilitate and or prohibit a crime from occurring, according to Meier and Miethe (1993). The victim of crimes can facilitate crimes committed against them. In the context of internet romance fraud, the offenders affirm this assertion, and it is confirmed by this study that victim facilitation ((0.315)/ 3.144) positively influences internet romance fraud. Victim provocation, according to Lasky (2018), implies victims overly get involved with the offender to the point where the victim is taken advantage of. This tendency of victims contributes to victimization. This study confirms this preposition and suggests that internet romance fraud victims overly indulge their online partners. The over indulgence of offenders leads to victimization. Victim provocation positively influences intention to commit internet romance fraud and this is partially supported by Petherick (2017) and Meier and Miethe (1993) in the context of some rape victims. 


\subsection{Study Implications}

The adaptive nature of victim precipitation has been confirmed in this study. The context of internet romance fraud enriches the literature in both criminology and information systems. It also highlights that although internet romance fraud is a criminal activity, victims may take some blame for the offenses committed against them. Expanding the theory of victim precipitation implies that the boundaries of this theory is extending with different dimensions and context coming into the debate. Operationalization of these constructs of victim provocation, victim facilitation and victim openness imply that empirical evidence is emerging to support victim precipitation theory.

With regards to the practice of law enforcement and prosecutions, practitioners of law have a new understanding of how victims contribute to their harm and loss. Understanding the offender's perspective of how victims harm themselves generates an additional mindset or psychological orientation of these scammers. Internet fraudster do not use neutralization and denial of risk techniques on the victims as they perceive that their victims are partly to blame for the harm that they suffer (Akanle et al., 2016; Lazarus, 2018).

\subsection{Implication for Practice}

According to Gilmour (2016), crimes are committed by different categories of offenders who adopt different criminology theories in their activities. There are many more techniques scammers or gamers of internet romance fraud use to defraud their victims including, neutralization denial of risk techniques (Offei et al., 2019, 2020), and now the victim precipitation dimensions of provocation, facilitation and openness of these victims they refer to as clients. Techniques and operationalize dimensions of the criminology theories of neutralization, denial of risk and victim precipitation have extended the frontiers of these theories in the criminology and information system literature. The contextualization of these theories in internet romance fraud brings a different understanding and insight to highlight offenders' perspectives of crimes committed by them. These insights offered by this study are relevant to the fight against internet romance fraud, and contribute to the reform of these criminals. Information dating and social media sites where these offenders recruit their clients.

According to Xu et al. (2013), for a crime to occur three conditions must exit: (1) a motivated criminal; (2) absence of a guardian; and (3) the suitable target. In the context of internet romance fraud, all these conditions are rife because the internet is anonymous it offers not much protection to the victims. The offenders target perceived rich victims who are mostly westerns.

\section{References}

Ajayi, M.O. and Okhankhuele, O.T., (2019). Effect of Training on the Performance of University Administrative staff in Nigeria. International Journal of Technology and Management Research, 4(1), pp.1-22. Akanle O., Adesina, J. O., \& Akarah, E. P. (2016). Towards human dignity and the internet: The cybercrime (yahooyahoo) phenomenon in Nigeria. African Journal of Science, Technology, Innovation and Development,

Chawki, M. (2009). Nigeria Tackles Advance Free Fraud. Journal of Information, Law E Technology (JILT).

Dhanani, L. Y., Main, A. M., \& Pueschel, A. (2020). Do you only have yourself to blame? A metaanalytic test of the victim precipitation model. J Organ Behav., 41: doi.org/10.1002/job.2413 
Jegede, A. E., Elegbeleye, A. O., Olowookere, E. I., \& Olorunyomi, B. R. (2016). Gendered alternative to cyber fraud participation: an assessment of technological driven crime in Lagos State, Nigeria. Gender and behaviour, 14(3), 7672-7692.

Lasky, N.V. (2019). Victim Precipitation Theory. John Wiley \& Sons, Inc. Published 2019 by John Wiley \& Sons, Inc.DOI: 10.1002/9781118929803.ewac0517

Lazarus S. (2018). Birds of a Feather Flock Together: The Nigerian Cyber Fraudsters (Yahoo Boys) and Hip Hop Artists. Criminology, Criminal Justice, Law \& Society and The Western Society of Criminology.

Meier, R. F., \& Miethe, T. D. (1993). Understanding Theories of Criminal Victimization. Crime and Justice, 17(1993), 459-499.

Modupe Olayinka Ajayi, Omonigho Tonia Okhankhuele. Effect of Training on the Performance of University Administrative staff in Nigeria, 2019; 4(1): 1-22

Offei, M., Andoh-Baidoo, F. A., Ayaburi, E., \& Asamoah, D. (2020). How Do Individuals Justify and Rationalize their Criminal Behaviors in Online Romance Fraud? Information Systems Frontiers; doi.org/10.1007/s10796-020-10051-2

Petherick, W. (2017). Victim Precipitation: Why we need to expand upon the Theory. Forensic Res Criminol Int. J., 5(2), 00148. DOI: 10.15406/frcij.2017.05.00148

Petherick, W., Arathi, K., \& Brooks, N. (2020). Victim Precipitation: An Outdated Construct or an Important Forensic Consideration? Journal of Forensic Psychology Research and Practice, DOI:10.1080/24732850.2020.1850087

Raharjo, A., \& Sudrajat, T. (Eds.). (2018, November). Legal Protection for Cyber Crime Victims on Victimological Perspective. In SHS Web of Conferences (Vol. 54, p. 08004). EDP Sciences.

Rege, A. (2009). What's Love Got to Do with It? Exploring Online Dating Scams and Identity Fraud, International Journal of Cyber Criminology (IJCC), 3(2): 494-512. ISSN: 0974 - 2891, July December 2009.

Sorell, T., \& Whitty, M.. (2019). Online romance scams and victimhood. Springer Nature Limited .

Warner, J. (2011). Understanding Cyber-crime in Ghana: A View from Below. International Journal of Cyber Criminology (IJCC), 5(1), 736-749. ISSN: 0974 - 2891 Jan - July 2011,

Wayne, P., \& Arathi, K. (2020). Victim Precipitation: An Outdated Construct or an Important Forensic Consideration? Journal of Forensic Psychology Research and Practice. DOI: $10.1080 / 24732850.2020 .1850087$

Whitty, M. T. (2018). 419 - It's just a Game: Pathways to Cyber Fraud Criminality emanating from West Africa. 